\title{
Assessment of obesity awareness stage of secondary school students
}

\author{
Mustafa Atl1 ${ }^{1}$, Zekiye Özkan ${ }^{1}$, and Burak Uyar $^{2 \mathrm{a}}$ \\ ${ }^{1}$ Yüzüncü Y1l University College of Physical Education and Sports, 65100,Van, Turkey \\ ${ }^{2}$ Yüzüncü Y1l University Faculty of Economic and Administrative Sciences Department of \\ Econometrics 65100,Van, Turkey
}

\begin{abstract}
In this study, it was aimed to investigate obesity awareness stage of 8th class students in secondary school who entered TEOG examination organized by Ministry of National Education in terms of different variables. The research was carried out with 268 male and 232 female students. Moreover, "Obesity Awareness Scale" developed by Allen (2011) and "and Turkish validity and reliability of which was performed by Kafkas\&Özen (2014) as well as Personal Information Form" were used. In the analysis of the research data, Student t-test, one-way variance analysis, SPSS software program were used as well as descriptive statistics. A statistically significance was observed between the students and their parents' habit of doing sports with total grades taken from the scale, obesity awareness and nutrition dimensions $(\mathrm{p}<0.05)$. A significant difference in favour of female students was determined between body mass index and gender in terms of statistics $(p<0.01)$. It was concluded that 268 male and 232 female students participated in this research had obesity awareness.
\end{abstract}

\section{Introduction}

WHO defines obesity as abnormal or excess accumulation of fat tissues in such a way that deranges the health [20]. Also Atl (2008) described obesity as a disease which emerges as a result of steatopygia in the body and which should be treated [4]. The generality of obesity increases in many countries. Especially in the countries which assimilates western life styles, this generality attracts the attention [10]. Childhood obesity has an increasing generality such as adult obesity. The reasons for this generality can be defined as differences in the compositions of the diet and decreasing activity form [11]. Global childhood obesity emerges with an increasing generality and difference as a secular trend all over the countries [29]. Childhood obesity has become an important health problem in

\footnotetext{
${ }^{\text {a }}$ Corresponding author: brkuyar@gmail.com
} 
USA with tripled rates in the last decade. Generality of childhood obesity drags the children into various diseases and other related health problems [2]. Increasing obesity takes the place of infectious diseases and under nutrition which derange the health [14]. Public health problem which reveals type 2 diabetes reflects the increasing rates of obesity in childhood [22]. Obesity is one of the most important health problems of our age which negatively affects life quality and length of life. In the studies, physiological part of obesity is mainly focused and psychosocial factors causing obesity are generally ignored [1]. Obesity is a serious public health problem prevalence of which increases incrementally all over the world. Obesity typically emerges as a result of interactions of environmental and genetic factors. It is considered that $40-70 \%$ of obesity variations depends on genetic factors [18]. The most effective way to stop or decrease obesity in childhood has not been discovered yet. Since obesity is a multi-factor problem, while biomedical researchers need metabolic, genetic, psychological and neurological researches, public health scientists, on the other hand, are concentrated on economical and social reasons in order to develop more effective researches. Now, it is more senseful to focus on unhealthy food content, the size of portion and inactive life styles [3]. In order to limit the obesity problem among children, global, regional and national projects are required [29]. Many researchers suggest physical activity to decrease the level of obesity to minimal. In the study of Bek (2012), physical activities are defined as activities which speed up the rate of respiration and heart and result in tiredness at different intensities and can be performed by using muscles and joints with energy consumption in a daily life [6]. If physical activity is presented in a suitable way, it might support development of social ability, behaviour, self-respect and post-school attitudes of children as well as development of cognitive and academic in some cases [5]. Developed physical education lectures might contribute to $97 \%$ of secondary school students potentially [23]. Increasing obesity rate and limiting the activity capabilities of children in school term result in negative results.

Playtime applications at school are not tools substituting physical education but they are complementary of them. They develop both activity and life style. Unconfigured playtime especially contributes to children for formation of new things and social as well as sensorial development. Playtime should be considered as personal time in terms of children being healthy and good and should not be relieved of due to punishment and academic reasons [21]. In order to increase the rate of physical activities of children, it is necessary to take significant steps for parents, school management and local managements.

\subsection{The Aim of the Research}

In this study, it was aimed to investigate the corralation between the obesity awareness stage of 8th class students in secondary school who entered TEOG examination organized by Ministry of National Education with different variables in terms of nutrition and physical activity sub-dimensions.

\subsection{The Problem of the Research}

It was aimed to find out whether the students in the secondary schools in our country have the obesity awareness, seeing the increasing obesity problems around the world. 


\section{Method}

In this research, it was aimed to investigate obesity awareness stage of 8th class students in secondary school who entered TEOG examination organized by Ministry of National Education in terms of different variables. Obesity awareness of students, nutrition and physical activity sub-dimensions were assessed in terms of different variables. In this survey model research, totally 500 students including 268 male and 232 female students getting education in secondary schools participated in spring term of 2015 education year. The average age of students was determined as $14.18 \pm 0.78$. In the research, "Obesity Awareness Scale" "' developed by Allen (2011) and Turkish validity and reliability of which was performed by Kafkas and Ozen (2014) as well as Personal Information Form were used. Body mass indexes of students were determined according to WHO-2007 BMI reference calculations [19]. The analysis of the research data, descriptive statistics as well as Student t-test and one-way variance analysis were carried out by SPSS software program.

\section{Findings}

In this survey model research, totally 500 students getting education in secondary schools participated in spring term of 2015 education year. In the research, 268 male and 232 female students were present. The average age of students was determined as $14.18 \pm 0.78$.

Table 1. Body mass index (BMI) in terms of gender

\begin{tabular}{lccc}
\hline \multirow{2}{*}{ BMI } & \multicolumn{2}{c}{ Gender } & \multirow{2}{*}{ Total } \\
\cline { 2 - 3 } Very thin & Male & Female & 20 \\
& 8 & 12 & $\% 4.0$ \\
Thin & $\% 1.6$ & $\% 2.4$ & 120 \\
& 46 & 74 & $\% 24.0$ \\
Normal & $\% 9.2$ & $\% 14.8$ & 289 \\
& 162 & 127 & $\% 57.8$ \\
Obese & $\% 32.4$ & $\% 25.4$ & 56 \\
& 41 & 15 & $\% 11.2$ \\
Very obese & $\% 8.2$ & $\% 3.0$ & 15 \\
& 11 & 4 & $\% 3.0$ \\
Total & $\% 2.2$ & $\% 0.8$ & 500 \\
& 268 & 232 & $\% 100$ \\
\hline
\end{tabular}

According to results of our research, it was observed that female students had better physical fitness than male students in body mass index calculation

Table 2. Obesity Awareness Grades and Sub-dimension grades

\begin{tabular}{lccc}
\hline & N & Average & Std. Dev. \\
\hline Obesity Awareness Total Grade & 500 & 58.28 & 8.66 \\
Obesity Awareness Sub-dimension & 500 & 23.29 & 4.13 \\
Nutrition sub-dimension & 500 & 18.29 & 3.46 \\
Physical sub-dimension & 500 & 13.58 & 2.44 \\
\hline
\end{tabular}

When the findings of the research were evaluated, it was determined that average of obesity awareness total grade obtained from the scale was 58.28, average of obesity awareness sub-dimension grade was 23.29, average of nutrition sub-dimension grade 18.29 and average of physical sub-dimension grade was 13.58 . 
Table 3.Obesity Awareness Grades and Sub-dimension grades in terms of Gender

\begin{tabular}{llcccc}
\hline & Gender & N & Average & Std. Dev. & p-value \\
\hline \multirow{2}{*}{ Obesity Awareness Total Grade } & Male & 268 & 58.24 & 8.69 & \multirow{2}{*}{$0.905^{*}$} \\
& Female & 232 & 58.33 & 8.63 & \\
Obesity Awareness Sub-dimension & Male & 268 & 23.39 & 4.19 & $0.539^{*}$ \\
& Female & 232 & 23.16 & 4.07 & \\
\multirow{2}{*}{ Nutrition sub-dimension } & Male & 268 & 18.31 & 3.49 & $0.912^{*}$ \\
\multirow{2}{*}{ Physical sub-dimension } & Female & 232 & 18.27 & 3.43 & \\
& Male & 268 & 13.40 & 2.41 & $0.081^{*}$ \\
\hline
\end{tabular}

Regarding gender, it was determined that total grade average of male students was 58.24 and that of female students was 58.33. When sub-dimensions present in the scale were investigated in terms of gender variable, it was found that average of obesity awareness grades for female students was 23.16, nutrition sub-dimension grade was 18.27, physical sub-dimension grade was 13.78. Average of obesity awareness grades for male students was 23.39, average of nutrition sub-dimension grade was 18.31 , average of physical sub-dimension grade was 13.40. A significant difference was not found between gender together with obesity awareness total grade and sub-dimensions $\left({ }^{*} \mathrm{p}>0.05\right)$.

In the study, a statistically significant difference was not found between educational status of mother and father, reading, period of television watching and habit of fast food nutrition as well as obesity awareness total grades and sub-dimensions ( $p>0.05)$. Moreover, it was observed that success rating of schools at which the students got education for TEOG examination did not affect obesity awareness $(\mathrm{p}>0.05)$.

Table 4. P-values of obesity awareness grades and sub-dimensions in terms of habit of doing sports

\begin{tabular}{lcc}
\hline & \multicolumn{2}{c}{ p-Value } \\
\cline { 2 - 3 } & Habit of doing sports & Habit of doing sports as parents \\
\hline Obesity Awareness Total Grade & $0.043^{*}$ & $0.011^{*}$ \\
Obesity Awareness Sub-dimension & $0.044^{*}$ & $0.010^{*}$ \\
Nutrition sub-dimension & 0.066 & $0.001^{* *}$ \\
Physical sub-dimension & 0.406 & 0.428 \\
\hline
\end{tabular}

It was observed that a significant difference was observed in terms of statistics between habit of doing sports for students and habit of doing sports for parents together with total grade obtained from the scale, obesity awareness and nutrition dimensions $(* \mathrm{p}<0,05)$.

Obesity awareness total grades and obesity awareness sub-dimension grade of the students doing sports and whose parents have a habit of doing sports were higher than others. If habit of doing sports in the parents was common, a significant difference in terms of statistics was observed in nutrition dimension of obesity awareness sub-dimension when compared to parents having less habit of doing sports $(* * \mathrm{p}<0.01)$.

Table 5. Body mass index (BMI) in terms of gender

\begin{tabular}{cccccc}
\hline & & N & Average & Std. Dev. & p-value \\
\hline BMI & Male & 268 & 3.00 & 0.78 & $* 0.00$ \\
BMI & Female & 232 & 2.67 & 0.75 & \\
\hline
\end{tabular}

A significant difference was determined in favour of female students between body mass index and gender $\left({ }^{*} \mathrm{p}<0.01\right)$. According to the results of our research, it was observed in the calculations of body mass index that female students had better physical fitness than male students. 


\section{Results and Discussion}

There are many evidences regarding the increase of obesity in our country and all over the world in recent years. It was observed that the sample group including secondary school students in Van city had obesity awareness. In this study, it was indicated that age and gender of secondary school students did not affect obesity awareness. Morover, it was observed that female students had better physical fitness than male students when body mass index calculations were taken into consideration. Obesity awareness total grade and nutrition dimension of students whose parents had a habit of doing sports was more positively affected than those whose parents did not have a habit of doing sports. In the study carried out by Ceylan and Turan (2008), the students' rate of obesity has been determined as $13.3 \%$. Statistically a significant difference has been found between being obese as well as obesity history in the family and doing physical activity. No statistically significant differences have been found between the students' age, gender, feeding habits and being obese. Ulutaş et al., (2014) expressed that there wasn't a relationship between obesity and gender. Moreover, it was determined that the obesity rate was higher for female students. Öztora (2005) stated that there wasn't a significant difference for obesity in terms of age and gender. In our study, it was determined that students doing sports perceived obesity awareness total grade, obesity awareness and nutrition sub-dimensions better. Semiz et al. (2008) found the obesity frequency low for 6-15 age sample group of Denizli city. That obesity increment is observed to be higher in schools with high socioeconomic levels is defined as the indicator showing that environmental factors are more efficient than genetic factors in our society. Also the attention is drawn to the inactive life style as well as easy access to foods and wrong feeding habits. It is stated that some precautions must be taken about this matter. In our study, no statistical significance $(p>0,05)$ has been found between the educational status of parents, reading, the duration of television watching, fast food feeding habits and obesity awareness total score and its sub-dimensions. Moreover, it has been seen that the success rating of the schools in which the students continue their education that the students get in the TEOG exam doesn't influence obesity awareness $(\mathrm{p}>0,05)$.

It was stated by Savaşhan et al. (2015) that nutrition habits and sedentary life had important role in childhood obesity. In the study they carried out with 3963 children between $6-11$ years old, 7,5\% of the children were defined as obese. It is stated that as the parents' BKI amount increases, the frequency of obesity of the children increases as well. The frequency of obesity has been defined higher for the children who spend more than four hours on computers and TVs daily. Hekim (2015) stated that physical activity and participation in sports were rather beneficial in the prevention of obesity resulting from inactive life style. The main point of obesity treatment was stated by Onal \&Adal (2014) as regulation of diets, changing the life style and increasing physical activities. It was stated by $\mathrm{Chu}(2001)$ that although gender percentages in obesity rates stayed constant from 1980 to 1994 , the trend and prevalence of obesity significantly increased in especially males and females older in age. In the study of Lee et al. (2009) which was carried out on 11 students between 11-13 years old selected among 1714 people and composed of 5 open-ended question, it was indicated that information was supplied for obese children to understand the perception of exercises better and that exercises can be beneficial for them as a part for the development of their health. In the study of Allen (2011) performed with 123 7th class students, pre and post-program nutritional food, the importance of physical activity and obesity awareness were evaluated with an educational intervention. It was stated that the study was effective to determine the obesity awareness of students and education about nutrition and diet were more effective on displaying the importance of physical activity [2]. In the study carried out by Metinoğlu et al (2012), even though obesity rate is not very high, 
researchers emphasize that precautions must be taken during childhood considering the obesity one of the important diseases in the future. In the study carried out by Şimşek et al (2005) on 1510 children between 6-17 years old, 4,8\% of the children were determined as obese. It is stated that obese children have low activity levels and wrong feeding habits. According to the researchers, obesity in school children is an important issue, and feeding habits and physical activity inadequacy as well as genetic susceptibility can affect obesity.

It was observed that significant relationships were found between obesity generality and period spent for watching television [9]. Sevimli \& Koçyiğit (2009) emphasized that informative meetings for children, parents, school management and trainers are important about the benefits of regular aerobic exercises to protect health and to enhance life quality.

In our study, when obesity awareness total grades of male and female students were investigated, it was concluded that "there is obesity awareness" in both groups and there was no significant difference in terms of statistics when gender variable was considered. It can be said that 268 male and 232 female students participated in this research had obesity awareness. In order to stop and decrease generality of childhood obesity which is spreading very rapidly in our country and all over the world, major tasks fall to experts in sports. Giving information to primary school students about healthy nutrition, formation of fields where they can do sports within school time and presenting these applications as part of education program will be beneficial for students to prevent childhood obesity.

\section{References}

1. Alaçam, H., Karadağ, R. F., \& Şengül, A. C. Obezite ve psikiyatri. Türkiye Klinikleri Journal of Endocrinology Special Topics, 6(1), 18-25 (2013)

2. Allen, A. Effects of educational intervention on children's knowledge of obesity risk factors. Phd Thesis, Carroll College (2011)

3. Aryana, M., Li, Z., \& Bommer, W. J. Obesity and physical fitness in california school children. American heart journal, 163(2), 302-312 (2012)

4. Atlı, M. Beden eğitimi ve spor. Göktuğ Yayın ve Dağıtım (2008)

5. Bailey, R.Physical education and sport in schools: A review of benefits and outcomes. Journal of school health, 76(8), 397-401 (2006)

6. Bek N., Fiziksel aktivite ve sağlığımız Sağlık Bakanlığı Yayın No: 730 İkinci Basım (2012)

7. Ceylan, S. S., \& Turan, T. Bir ilköğretim okulunda 11-14 yaş arasındaki öğrencilerde obezite sıklığ 1 ve etkileyen etmenler, Atatürk Üniversitesi Hemşirelik Yüksekokul Dergisi 11(4). (2008).

$8 \mathrm{Chu}$ N-F. prevalence and trends of obesity among school children in taiwan -the taipei children heart study International Journal of Obesity 25, 170-176 (2001)

9. Dietz, W. H., \& Gortmaker, S. L. do we fatten our children at the television set? obesity and television viewing in children and adolescents. Pediatrics, 75(5), 807-812. (1985).

10. Gedik, O. Obezite ve çevresel faktörler. Turkish Journal of Endocrinology and Metabolism, 2, 1-4 (2003)

11. Gürel S. , \& İnan G. , Çocukluk çağı obezitesi tanı yöntemleri, prevalansı ve etyolojisi. ADÜ Tıp Fakültesi Dergisi ; 2(3) : 39 - 46 (2001)

12. Hekim, M., Çocukluk çağı obezitesinin önlenmesinde fiziksel aktivite ve sporun önemi, Uluslararası Sosyal Araştırma Dergisi 8(37). (2015)

13. Kafkas, M.E., \& Özen, G. Obezite farkındalık ölçeğinin (ofö) türkçeye uyarlanması: bir geçerlilik ve güvenirlik çalışması, İnönü Üniversitesi Beden Eğitimi ve Spor Bilimleri Dergisi 1(2):1-15 (2014)

14. Kopelman, P. G. Obesity as a medical problem. Nature, 404 635-643 (2000) 
15 Lee, P. H., Lai, H. R., Chou, Y. H., Chang, L. I., \& Chang, W. Y. Perceptions of exercise in obese school-aged children. Journal of Nursing research, 17(3), 170-178 (2009)

16. Metinoğlu, İ., Pekol, S., \& Metinoğlu, Y. (2012). Kastamonu'da 10-12 yaş grubu öğrencilerde obezite prevalansı ve etkileyen faktörler. Acıbadem Üniversitesi Sağlık Bilimleri Dergisi Cilt: 3 • Sayı: 2 • (Nisan 2012).

17. Önal, Z., Adal E., Çocukluk çağında obezite, Okmeydanı Tıp Dergisi Ek sayı 1:39-44 (2014)

18. Önder, E., \& Aydın, Y. Obezite genetiği. Turkiye Klinikleri Journal of Endocrinology Special Topics. 6(1):13-17 (2013)

19. Onis, M. D., Onyango, A. W., Borghi, E., Siyam, A., Nishida, C., \& Siekmann, J. Development of a WHO growth reference for school-aged children and adolescents. Bulletin of the World Health Organization, 85(9), 660-667 (2007)

20. Öztora S. Ilköğretim çağındaki çocuklarda obezite prevalansının belirlenmesi ve risk faktörlerinin araştırılması T.C. Sağlık Bakanlığı Bakırköy Dr. Sadi Konuk Eğitim ve Araştırma Hastanesi Dr. Sami Hatipoğlu Çocuk Sağlığı ve Hastalıkları Kliniği Şefi ve Aile Hekimliği Koordinatörü Uzmanlık Tezi, İstanbul (2005)

21. Ramstetter, C. L., Murray, R., \& Garner, A. S. The crucial role of recess in schools. Journal of School Health, 80(11), 517-526 (2010)

22. Rosenbloom, A. L. İncreasing incidence of type 2 diabetes in children and adolescents. treatment considerations. Pediatric Drugs, 4(4), 209-221 (2002)

23. Sallis, J. F., McKenzie, T. L., Alcaraz, J. E., Kolody, B., Faucette, N., \& Hovell, M. F. The effects of a 2-year physical education program (spark) on physical activity and fitness in elementary school students. American journal of public health, 87(8), 13281334 (1997)

24. Savaşhan, Ç .,Sarı, O., \& Aydoğan, Ü., Erdal, M. İlkokul çağındaki çocuklarda obezite görülme sıklığı ve risk faktörleri. Türkiye Aile Hekimliği Dergisi, 19(1), 2-9 (2015)

25. Simsek, F., Ulukol, B., Berberoglu, M., Gulnar, S. B., Adiyaman, P., \& Ocal, G. The prevalence of obesity in a primary school and high school in Ankara. Ankara University Med J, 58, 163-6 (2005)

26. Semiz, S., Özdemir, Ö.M., \& Özdemir, A.S. Denizli il merkezde 6-15 yaş grubu çocuklarda obezite sıklığı, Pamukkale Tıp Dergisi 1: 1-4 (2008)

27. Sevimli, D., \& Koçyiğit, F. Çocuklarda aerobik egzersizin kardiopulmoner sistemdeki etkileri. TAF Preventive Medicine Bulletin, 8(2), 125-130 (2009)

28. Ulutaş, A.P., Atla, P., Say, Z.A., \& Sarı, E., Okul çağındaki 6-18 yaş arası obez çocuklarda obezite oluşumunu etkileyen faktörlerin araştırılması, Zeynep Kamil Tıp Bülteni, 45(4), 192-196 (2014)

29. Wang, Y., \& Lobstein, T. Worldwide trends in childhood overweight and obesity. International Journal of Pediatric Obesity, 1(1), 11-25 (2006). 